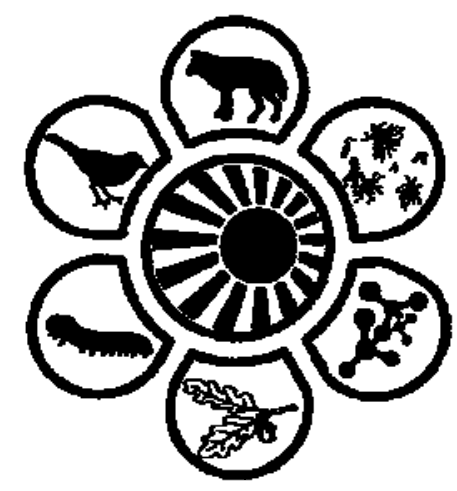

Вісник Дніпропетровського університету. Біологія, екологія.

Vìsnik Dnìpropetrovs'kogo unìversitetu. Seriâ Bìologiâ, ekologiâ

Visnyk of Dnipropetrovsk University. Biology, ecology.

Vìsn. Dnìpropetr. Unìv. Ser. Bìol. Ekol. 2014. 22(1), 60-65.

doi: $10.15421 / 011408$

ISSN 2310-0842 print

ISSN 2312-301X online

www.ecology.dp.ua

\title{
УДК 598.2:591.5 (477.5) \\ Розмір кладки та успішність розмноження синиці великої (Parus major) та блакитної (P. caeruleus) у парках м. Харків
}

\author{
А.Б. Чаплигіна, Д.І. Бондарець, Н.О. Савинська \\ Харківський національний педагогічний університет імені Г.С. Сковороди, Харків, Украйна
}

\begin{abstract}
Установлено середній розмір повної кладки синиці великої 8,9 $\pm 0,35(n=61)$ та синиці блакитної 9,5 $\pm 0,33(n=12)$. У синиці великої більшу частину складають $10-(33,5 \%)$ та 9-яйцеві $(16,7 \%)$ кладки. У синиці блакитної переважають 10 -яйцеві $(25,0 \%)$ кладки у Журавлівському гідропарку та 12 -яйцеві (17,5\%) - у парку імені М. Горького. Встановлено високу успішність розмноження у синиці великої $(85,1 \%)$ та блакитної $(84,0 \%)$. У середньому на одну пару синиці великої із гнізда злітає $5,1 \pm 0,16$ пташеняти, у синиці блакитної - 8,5 $\pm 0,38$ пташеняти. Це свідчить про стабільність урбопопуляції. Протягом існування популяції у синиці великої виявлено залежність зменшення успішності розмноження: у Журавлівському гідропарку у рік розміщення штучних гніздівель із гнізд злетіло у середньому $6,7 \pm 0,12$ пташеняти на одну пару, упродовж чотирьох років ця величина зменшилась майже удвічі і становила $3,6 \pm 0,15$. У синиці блакитної такої залежності не виявлено. Найпродуктивнішими у синиці великої виявилися кладки третьої декади квітня $(89,7 \%)$, що у середньому складає $8,9 \pm 0,78$ пташеняти на одну пару. Найуспішнішими $є 10$-яйцеві кладки, частка зльоту пташенят із яких становила $98,3 \%$, що у середньому складає $9,8 \pm 0,18$ на одну пару.
\end{abstract}

Ключові слова: синиця велика; синиця блакитна; розмір кладки; успішність розмноження; урболандшафт

\section{Clutch size and breeding success of great tit (Parus major) and blue tit ( $P$. caeruleus) in the parks of Kharkiv city}

\author{
A. Chaplygina, D. Bondarets, N. Savynskaya \\ G.S. Skovoroda Kharkiv National Pedagogical University, Kharkiv, Ukraine
}

The analysis of clutch size and breeding success of great tits and blue tits is conducted using 115 nests: 92 great tits and 23 blue tits. Nest boxes for small passerine birds were made in 2009-2013 and placed in the city parks in order to improve their ecological condition. Thus, the experimental plots were established in the Central park of culture and recreation named after M. Gorky in the number of 37 nest boxes in the area of about $5 \mathrm{ha}$; in the territory of Zhuravlevskiy hydropark in the amount of 30 units on two sites on each of 4 ha and 20 units on an area of 2 ha. 20 nest boxes were placed in the forest park along the central motorway of the city. All the nest boxes were placed by the group method (distance between nest boxes was about $10-15 \mathrm{~m}$ ) at height to $3 \mathrm{~m}$, and entrance diameter of $3 \mathrm{~cm}$. The front wall in such nest boxes is taken out, thus facilitating their further verification carried out during the period from the first ten-day period of April till the second tenday period of July up to ten times. It was shown that the average size of the full clutch for great tits amounted to $8.9 \pm 0.35(n=61)$ and for blue tits $9.5 \pm 0.33(n=12)$. The great tits has the largest proportion of $10(33.5 \%)$ and 9 eggs $(16.7 \%)$ in the clutch. For the blue tits the dominating figure was 10 egg (25.0\%) in the clutch of Zhuravlevskiy hydropark and 12 eggs (17.5\%) in the clutch in the Gorky park. We determined high success of reproduction for great tits $(85.1 \%)$ and blue tits $(84.0 \%)$. On average, per one pair of great tits and blue tits $5.1 \pm$ 0.16 and $8.5 \pm 0.38$ chicks, respectively, flied the nests. The decreased parameter in breeding success during the existence of an artificial population of great tits was revealed. For example, in Zhuravlevskiy hydropark on average $6.7 \pm 0.12$ chicks per pair flied the nests during the year of placing the nest boxes. During four years, this value decreased almost by half and amounted to $3.6 \pm 0.15(P<0.05)$. For blue tits this dependence was not found. The most productive clutches for great tits were clutches of the third ten-day period in April ( $89.7 \%)$, which on average amounted to $8,9 \pm 0.78$ chicks per pair. The most successful were ten egg clutches. Share of takeoff chicks amounted to $98.3 \%$, which on average amounted to $9.8 \pm 0,18$ chicks per pair.

Keywords: great tit; blue tit; clutch size; breeding success; urbanized landscape

Харківський наиіональний педагогічний університет імені Г.С. Сковороди, вул. Артема, 29, Харків, 61002, Украӥна. Skovoroda Kharkiv National Pedagogical University, Artema str., 29, Kharkiv, 61002, Ukraine.

Tel.: +38-050-618-18-96.E-mail: iturdus@ukr.net 


\section{Вступ}

Кількість нормальних кладок і виводків за сезон розмноження - ознака популяційна, а не видова. У птахів-дуплогніздників існування других і третіх кладок та їх розмір залежать від багатьох факторів, що впливають на розмноження. Основні із цих факторів - строки гніздування популяції та географічне місце розташування, біотоп, щільність та іiі віковий склад, особливості клімату та погоди (Howe, 1978; Lloyd, 1979; Becker, 1982). Відома залежність внутрішньо- та міжпопуляційної варіабельності строків відкладання та розміру кладки від кліматичних коливань у синиць великої та блакитної (Orell and Ojanen, 1983; Sanz, 2002). Проте іноді дослідники вказують на нездатність синиць адаптувати розмір кладки до умов середовища, в якому вони розмножуються (Dnondt et al., 1990).

Генетична гетерогенність популяцій синиці великої $\epsilon$ важливим параметром успішності розмноження (Tomiuk et al., 2007), яка може залежати як від особливостей зимового виживання особин (Koivula et al., 1996), так і від наслідків розпадання пар (Orell, 1994). Установлено залежність між сезонністю корму, успішністю розмноження та розміром тіла пташенят синиці блакитної (Dias and Blondel, 1996). Досліджено розмір виводка цієї синиці від наявності генетичних і екологічних складових росту, використовуючи метод гібридного схрещування (Kunz and Ekman, 2000). Позитивно на успішність розмноження впливає мікросередовище з точки зору маскування, підтримки гнізд, топографічного розташування тощо (Newell and Rodewald, 2011). На продуктивність розмноження не суттєво впливає висота гнізда, більш значущим є вік самки, рік гніздування, тип кладки та дата відкладання яєць (Lambrechts et al., 2012). 3 іншого боку, успішність вилуплення пташенят негативно корелює з термінами сінокосу чи затопленням у низинних луках (Broyer, 2009).

Відомо про вплив антропогенного шуму на репродуктивні показники птахів, які населяють територіі, розташовані уздовж основних транспортних зв'язків (автомагістралі, залізничні коліі) (Slabbekoorn and Ripmeester, 2008; Barber et al., 2009; Bobyliov et al., 2014). Загалом негативний вплив шуму дорожнього руху на птахів залежить від часового та просторового перекривання з відповідними акустичними звуками (Brumm and Slabbekoorn, 2005).

Птахи використовують різні вокалізації протягом доби, проте більшість видів обмежується використанням пісні, яка є важливою для територіальної охорони, для приваблення самок на світанку (Catchpole and Slater, 2008) та оцінки якості самця (Holveck and Riebel, 2009). Перекриття між піснею на світанку та піками активності руху (наприклад, «час пік») можуть бути важливим фактором у з'ясуванні негативного впливу та залежати у першу чергу від пори року, відповідно до довготи та широти місцевості (Warren et al., 2006). Оцінка залежності рівня шуму від часу - важливий крок до розуміння, коли шум найсильніше перекривається з вокальною активністю птахів (Slabbekoorn and Ripmeester, 2008; Barber et al., 2009). Просторове перекриття найпомітніше для вокалізації птахів на низьких частотах, у той час як шум дорожнього руху найгучніший на низьких частотах (Pohl et al., 2009), а низькі звуки послаблюються менше 3 відстанню та щільністю рослинності (Padgham, 2004). Птахи можуть сприймати шумні території як низькоякісні та намагатися уникати таких територій (Slabbekoorn and Ripmeester, 2008).

Підвищення рівня шуму є причиною фізіологічного стресу через зменшення можливостей добувати корм, оскільки здобич важче знайти (Schaub et al., 2008), або тому, що більше часу доводиться витрачати для виявлення хижаків (Quinn et al., 2006). Шум може впливати на зв'язок «батьки - потомство», і дорослі можуть таким чином не бути спроможними задовольняти потреби пташенят (Leonard and Horn, 2008).

Передача шуму вуличного руху залежить від архітектури будівель навколо автомагістралі, від грунту та структури рослинності (Bucur, 2006). Шумова амплітуда сильно пов'язана зі швидкістю вуличного pyху (Makarewicz and Kokowski, 2007). Розмір кладки, успішність вилуплення та кількість оперених пташенят позитивно корелюють зі швидкістю орієнтації птахів у шумному просторі. Природний добір може безпосередньо впливати на зміни особин у вирішенні проблем продуктивності (Cauchard et al., 2013).

Успішність розмноження та благополуччя можуть знижуватися, але щільність гніздування залишається високою за рахунок компенсації впливу шуму на темпи хижацтва (Francis et al., 2009) чи конкуренції за корм (Slabbekoorn and Halfwerk, 2009). Міжрічна пластичність концентрації кортикостерону у самців була пов'язана 3 наявністю достатньої кількості корму протягом року (надлишок або нестача) (Ouyang et al., 2013).

На території України синиці як група дуплогніздних птахів детально вивчені на Поділлі (Matveev, 1998). Подібні дослідження не відомі для Харківської області, що дає підстави до подальшого вивчення основних репродуктивних показників в урбанізованому ландшафті у південній межі Лісостепу. Мета наших досліджень вивчити розмір кладки та успішність розмноження синиці великої та синиці блакитної залежно від екологічних факторів, задля поліпшення умов існування та охорони їх в урболандшафті.

\section{Матеріал і методи досліджень}

Дослідження проводили протягом 2009-2013 років у парках Харкова. Площа зелених масивів міста представлена різними насадженнями, які складають 5200 га, 3 них 2500 припадає на лісопарк, який $\epsilon$ найбільшою лісопарковою зоною України. У 2009-2013 роках ми виготовили штучні гніздівлі для дрібних горобцеподібних птахів, розвісили у парках і скверах міста 3 метою поліпшення їх екологічного стану. Таким чином були закладені дослідні ділянки у Центральному парку культури та відпочинку імені М. Горького на території Харківського лісопарку (37 штучних гніздівель на площі близько 5 га), на території Журавлівського гідропарку (по 30 штук на двох ділянках по 4 га кожна та 20 - на ділянці площею 2 га), 20 штучних гніздівель у лісопарку уздовж центральної автомагістралі міста. Всі штучні гніздівлі розташовані груповим методом (відстань між 
гніздівлями 10-15 м), на висоті до 3 м, мали льоток діаметром 3 см. Передня стінка у таких штучних гніздівель виймається, що полегшує у подальшому їх перевірку, яку здійснювали з I декади квітня по II декаду липня до 10 разів.

Знайдено 115 гнізд синиць: 92 великої та 23 блакитної. Визначення строків розмноження птахів проводили за датою відкладання першого яйця. Оцінку репродуктивних показників проводили за такими параметрами: успішність вилуплення (ефективність інкубації), успішність постембріонального гніздового періоду та успішність гніздування (Paevsky, 1985). Успішність вилуплення пташенят визначали за формулою: $n_{p} / n_{e} \cdot 100 \%$; де $n_{e}-$ кількість яєць, $n_{p}$ - кількість пташенят, які вилупились. Успішність постембріонального гніздового періоду визначали за формулою: $n_{p 2} / n_{p 1} \cdot 100 \%$, де $n_{p 1}-$ кількість пташенят, які вилупилися, $n_{p 2}-$ кількість пташенят, які оперились. Причини загибелі потомства визначені спостереженням за 83 гніздами синиці великої, в яких містилося 585 яєць і 13 гніздами синиці блакитної - 123 яйця на всіх ділянках міста Харкова. Статистичний аналіз отриманих результатів здійснювали з використанням програми Statistica 6.0.

\section{Результати та їх обговорення}

У сезон розмноження синиця велика та синиця блакитна мають один цикл. Повторні кладки виникають у результаті загибелі перших. Розмір кладки може корелювати 3 датою відкладання яєць, яка опосередковано залежить від рівня шуму. Останній має незалежний негативний вплив на розмір кладки у самок, які відкладали у середньому на $10 \%$ менше яєць через градієнт шуму 20 дБ. Рівень шуму має негативний вплив на масу оперених пташенят. Високий рівень шуму у квітні корелює 3 низькою кількістю оперених пташенят. Розмір кладки може впливати на кількість оперених пташенят. Шум у діапазоні частот близько 2 кГц частково покриває нижню частину пісні великої синиці та має негативний вплив на кількість яєць, відкладених самками (Halfwerk and Slabbekoorn, 2009).

У парках міста повні кладки синиці великої $(n=83)$ становлять від 5 до 13 яєць, у середньому 8,9 $\pm 0,35$. Найбільшу частку складають $10-(33,5 \%)$ та 9-яйцеві $(16,7 \%)$ кладки. Аналіз окремо за кожним із парків показав, що в Журавлівському гідропарку також переважають 10- (27,5 \%) та 9-яйцеві (15\%) кладки. У Лісопарку та парку імені М. Горького знайдено більше 11-яйцевих кладок (по 3,5\% на кожній території), 13-яйцеві (2,5\%) кладки є винятком і зареєстровані тільки в лісопарку.
Повні кладки синиці блакитної $(n=13)$ становлять від 5 до 14 яєць, у середньому 9,5 $\pm 0,33$. Більшу частку містять 10-яйцеві $(25,0 \%)$ кладки у Журавлівському гідропарку та 12-яйцеві (17,5\%) у парку імені М. Горького. У Лісопарку знайдені 12-яйцеві $(8,0 \%)$ та 14-яйцеві $(8,0 \%)$ кладки (табл. 1$)$.

На успішність розмноження птахів впливають фактори зовнішнього середовища та внутрішньопопуляційні чинники. До перших можна віднести хижацтво, погодні умови, ресурси корму, строки розмноження, гніздовий паразитизм, до других - ембріональну смертність, вік батьків і сталість пар, щільність популяції та соціально зумовлену смертність пташенят, ступінь розвитку полігамії у популяції та інші особливості шлюбних систем. Під успішністю розмноження розуміють ступінь збереження яєць і пташенят до моменту вильоту із гнізд. На території Парку імені М. Горького та Лісопарку середній показник успішності розмноження синиці великої становить $64,4 \%(n=110)$, що складає $5,1 \pm 0,75$ пташеняти, які злетіли із гнізда на одну пару птахів; у синиці блакитної - 92,3\% $(n=50)$ та $11,5 \pm 0,17$ відповідно. В окремі роки у синиці великої цей показник може змінюватись від 42,3\% $(n=26,2,7 \pm 0,47$ на одну пару) у 2012 до $85,7 \%$ ( $n=35,6,0 \pm 0,62$ на одну пару) у 2013 році (табл. 1, рис.).

На території Журавлівського гідропарку середній показник успішності розмноження синиці великої становить 76,9\% ( $n=475,5,3 \pm 0,25$ на одну пару птахів), у синиці блакитної - 75,5\% ( $n=73,6,1 \pm 0,25$ на одну пару птахів, які приступили до розмноження). В окремі роки у синиці великої цей показник може змінюватись від $58,2 \%$ ( $n=67,3,6 \pm 0,32$ на одну пару) у 2013 до 93,0\% ( $n=201,6,7 \pm 0,34$ на одну пару) у 2010 році; у синиці блакитної - від 77,8\% ( $n=9,7,0 \pm 0,43$ на одну пару) у 2013 до 100,0\% ( $n=34,11,3 \pm 0,08$ на одну пару) у 2010 році (табл. 2).

Успішність розмноження синиць протягом 20102013 років на території Харкова висока та стабільна $85,1 \%(n=552)$ у синиці великої та $84,0 \%(n=112)$ у синиці блакитної. У середньому на одну пару синиці великої з гнізда злітає $5,1 \pm 0,16$, у синиці блакитної - 8,5 $\pm 0,38$ пташеняти. Виявлено залежність зменшення успішності розмноження у синиці великої протягом існування штучної популяції: у Журавлівському гідропарку у рік розміщення штучних гніздівель із гнізд злетіло у середньому 6,7 $\pm 0,12$ пташеняти на одну пару, упродовж чотирьох років ця величина зменшилась майже удвічі - до $3,6 \pm 0,15$ ( $P<0,05)$. Для синиці блакитної такої залежності не виявлено (табл. 2).

Таблиия 1

Хронологічна мінливість успішності та продуктивності розмноження $\left(x \pm S_{x}\right)$ синиці великої та синиці блакитної на території Парку імені М. Горького та Лісопарку, 2011-2013 рp.

\begin{tabular}{|c|c|c|c|c|c|c|c|c|c|c|c|c|}
\hline \multirow{3}{*}{ Рік } & \multicolumn{6}{|c|}{ Parus major } & \multicolumn{6}{|c|}{ P. caeruleus } \\
\hline & \multirow[b]{2}{*}{$n$} & \multirow{2}{*}{$\begin{array}{c}\text { середній } \\
\text { розмір } \\
\text { кладки }\end{array}$} & \multicolumn{2}{|c|}{ вилупилось пташенят } & \multicolumn{2}{|c|}{ вилетіло пташенят } & \multirow[b]{2}{*}{$n$} & \multirow{2}{*}{$\begin{array}{c}\text { середній } \\
\text { розмір } \\
\text { кладки }\end{array}$} & \multicolumn{2}{|c|}{ вилупилось пташенят } & \multicolumn{2}{|c|}{ вилетіло пташенят } \\
\hline & & & $\%$ & $\begin{array}{l}\text { у середньому } \\
\text { на одну пару }\end{array}$ & $\%$ & $\begin{array}{l}\text { у середньому } \\
\text { на одну пару }\end{array}$ & & & $\%$ & $\begin{array}{l}\text { у середньому } \\
\text { на одну пару }\end{array}$ & $\%$ & $\begin{array}{l}\text { у середньому } \\
\text { на одну пару }\end{array}$ \\
\hline 2011 & 5 & $9,8 \pm 0,35$ & 73,5 & $7,2 \pm 0,50$ & 65,3 & $6,4 \pm 0,42$ & 1 & 12,0 & 100,0 & 12,0 & 100,0 & 12,0 \\
\hline 2012 & 4 & $6,5 \pm 0,23$ & 61,5 & $4,0 \pm 0,45$ & 42,3 & $2,7 \pm 0,47$ & 1 & 12,0 & 100,0 & 12,0 & 100,0 & 12,0 \\
\hline 2013 & \begin{tabular}{|l|}
5 \\
\end{tabular} & $7,0 \pm 0,40$ & 85,7 & $6,0 \pm 0,35$ & 85,7 & $6,0 \pm 0,62$ & 2 & 13,0 & 76,9 & 10,0 & 76,9 & 10,0 \\
\hline Разом & 14 & 110 & 73,6 & $5,8 \pm 0,80$ & 64,4 & $5,1 \pm 0,75$ & 4 & $12,5 \pm 0,30$ & 92,3 & $11,5 \pm 0,25$ & 92,3 & $11,5 \pm 0,25$ \\
\hline
\end{tabular}


Таблиия 2

Хронологічна мінливість успішності та продуктивності розмноження $\left(x \pm S_{x}\right)$ синиці великої та синиці блакитної на території Журавлівського гідропарку, 2010-2013 рр.

\begin{tabular}{|c|c|c|c|c|c|c|c|c|c|c|c|c|}
\hline \multirow{3}{*}{ Рік } & \multicolumn{6}{|c|}{ Parus major } & \multicolumn{6}{|c|}{ P. caeruleus } \\
\hline & \multirow[b]{2}{*}{$n$} & \multirow{2}{*}{\begin{tabular}{|c|} 
середній \\
розмір \\
кладки
\end{tabular}} & \multicolumn{2}{|c|}{ вилупилось пташенят } & \multicolumn{2}{|c|}{ вилетіло пташенят } & \multirow[b]{2}{*}{$n$} & \multirow{2}{*}{$\begin{array}{c}\text { середній } \\
\text { розмір } \\
\text { кладки }\end{array}$} & \multicolumn{2}{|c|}{ вилупилось пташенят } & \multicolumn{2}{|c|}{ вилетіло пташенят } \\
\hline & & & $\%$ & $\begin{array}{l}\text { у середньому } \\
\text { на одну пару }\end{array}$ & $\%$ & $\begin{array}{l}\text { у середньому } \\
\text { на одну пару }\end{array}$ & & & $\%$ & $\begin{array}{l}\text { у середньому } \\
\text { на одну пару }\end{array}$ & $\%$ & $\begin{array}{l}\text { у середньому } \\
\text { на одну пару }\end{array}$ \\
\hline 2010 & 28 & $7,2 \pm 0,54$ & 93,03 & $6,7 \pm 0,34$ & 93,03 & $6,7 \pm 0,34$ & 3 & 11,3 & 100,0 & 11.0 & 100,0 & 11,3 \\
\hline 2011 & 0 & $7,5 \pm 0,37$ & 83,9 & 6,2 & 3,9 & 75 & 2 & 5, & 80,0 & 4.0 & 80,0 & 4,0 \\
\hline 2012 & 10 & $5,8 \pm 0,45$ & 72,4 & $4,2 \pm 0,67$ & 72,4 & $4,2 \pm 0,67$ & 3 & 6,7 & 45,0 & 3.0 & 45,0 & 3,0 \\
\hline 2013 & 11 & $6,1 \pm 0,39$ & 80,6 & $4,9 \pm 0,32$ & 58,2 & $3,6 \pm 0,32$ & 1 & 9,0 & 77,8 & 7.0 & 77,8 & 7,0 \\
\hline Разом & 69 & $6,9 \pm 0,65$ & 82,5 & $5,7 \pm 0,25$ & 76,9 & $5,3 \pm 0,25$ & 9 & $8,1 \pm 0,18$ & 75,7 & $6.1 \pm 0.25$ & 75,7 & $6,1 \pm 0,25$ \\
\hline
\end{tabular}

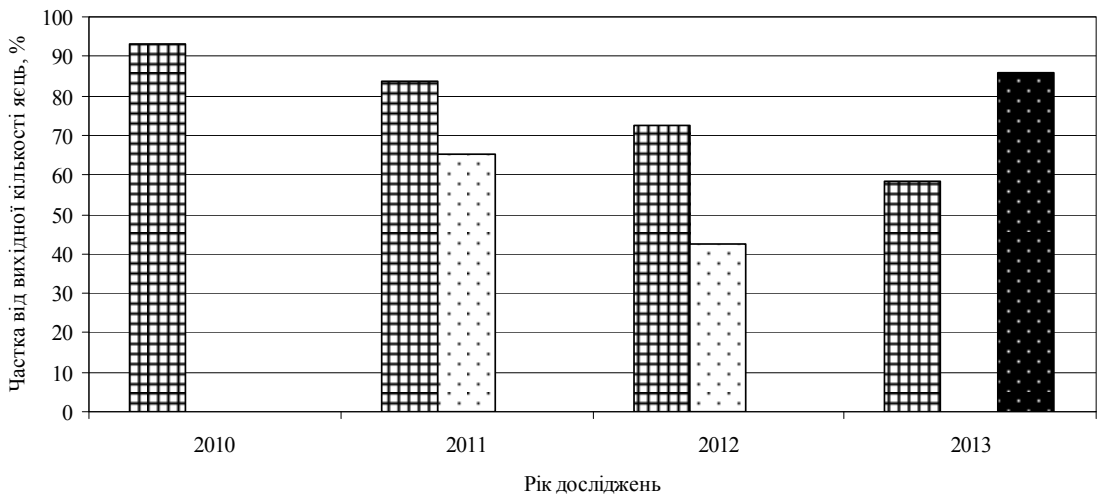

Ð Журавлівський гідропарк $\square$ Парк ім. М. Горького $\mathbf{\square}$ Лісопарк

Рис. Хронологічна мінливість успішності розмноження синиці великої на території м. Харків, 20102013 рр.

Продуктивність розмноження синиці великої упродовж репродуктивного періоду змінюється за рахунок початку яйцевідкладання, кормових умов і піку розмноження хижаків. В особин із високою вихідною концентрацією кортикостерону на початку розмноження у березні була найвища кількість вилуплених пташенят на рік; у травні особини з низьким рівнем кортикостерону мали найвищу успішність розмноження. Крім цього, особини, які відображають сильну сезонну пластичність в основній лінії концентрації кортикостерону (висока у березні та низька у травні), мають найвищу успішність розмноження кожного року (Ouyang et al., 2013).

На території парків Харкова у синиці великої продуктивними виявилися кладки третьої декади квітня $89,7 \%$ ( $n=40,8,9 \pm 0,78$ пташеняти на одну пару). Високий показник розмноження синиці великої у першій та другій декадах червня вважали за виняток через незначну вибірку (табл. 3). У випадку біциклічного гніздування синиці великої в Анталії (північна Туреччина) середня кількість оперених пташенят у парі достовірно вища у перших виводках $(P<0,05)$. Однакове співвідношення у виводку самців і самок $(0,53$ / 0,47), $є$ результатом збалансованого статевого співвідношення, яке передбачає стабільну структуру популяції (Bekir and Tamer, 2012).

Кладки 3 оптимальним розміром забезпечують оптимальний рівень успішності (Lack, 1968). Аналіз успішності розмноження синиці великої від розміру кладки на територіях парків Харкова показав, що найпродуктивнішими були 10-яйцеві кладки. Частка пташенят, які залишили гнізда становила 98,3\% (9,8 \pm 0,18 на одну пару). В окремі роки частка пташенят, які залишили гнізда була $76,7 \%$ при розмірі у п'ять яєць (3,8 $\pm 0,17$ пташенят). При $100 \%$ успішності розмноження 6-яйцевих кладок пташенят злітало також значно менше, ніж при 10-яйцевих кладках. 13-яйцеві кладки були малочисельними, тому ми їх не враховували (табл. 4).

Успішність розмноження синиці великої $\left(x \pm S_{x}\right)$ залежно від строків яйцевідкладання

Табличя 3 на території парків Харкова, 2010-2013 pp.

\begin{tabular}{|c|c|c|c|c|c|c|}
\hline \multirow{2}{*}{$\begin{array}{c}\text { Строки початку } \\
\text { відкладання яєць }\end{array}$} & \multicolumn{2}{|c|}{ Кількість } & \multicolumn{2}{|c|}{ Вилупилось пташенят } & \multicolumn{2}{|c|}{ Вилетіло пташенят } \\
\cline { 2 - 7 } & кладок & яєць у гніздах & \multirow{2}{*}{$\begin{array}{c}\text { частка від вихідного } \\
\text { числа яєць, } \%\end{array}$} & $\begin{array}{c}\text { у середньому } \\
\text { на одну пару }\end{array}$ & $\begin{array}{c}\text { частка від вихідного } \\
\text { числа яєць, \% }\end{array}$ & $\begin{array}{c}\text { у середньому } \\
\text { на одну пару }\end{array}$ \\
\hline $21.04-30.04$ & 40 & 397 & 93,5 & $9,3 \pm 0,56$ & 89,7 & $8,9 \pm 0,78$ \\
\hline $01.05-10.05$ & 8 & 71 & 76,1 & $6,8 \pm 0,45$ & 69,0 & $6,1 \pm 0,57$ \\
\hline $11.05-20.05$ & 5 & 29 & 75,9 & $4,4 \pm 0,60$ & 62,1 & $3,6 \pm 0,45$ \\
\hline $21.05-31.05$ & 6 & 40 & 67,5 & $4,4 \pm 0,33$ & 67,5 & $4,4 \pm 0,33$ \\
\hline $01.06-11.06$ & 1 & 10 & 100,0 & 10,0 & 100,0 & 10,0 \\
\hline $11.06-20.06$ & 1 & 5 & 100,0 & 5,0 & 100,0 & 5,0 \\
\hline
\end{tabular}


Успішність розмноження синиці великої $\left(x \pm S_{x}\right)$ залежно від розміру кладки на території парків Харкова, 2010-2013 рp.

\begin{tabular}{|c|c|c|c|c|c|c|}
\hline \multirow{2}{*}{ Розмір кладки } & \multicolumn{2}{|c|}{ Кількість } & \multicolumn{2}{c|}{ Вилупилося пташенят } & \multicolumn{2}{c|}{ Вилетіло пташенят } \\
\cline { 2 - 7 } & кладок & яєць у гніздах & $\begin{array}{c}\text { частка від } \\
\text { відкладених ясць, } \%\end{array}$ & $\begin{array}{c}\text { у середньому } \\
\text { на одну пару }\end{array}$ & $\begin{array}{c}\text { частка від } \\
\text { відкладених ясць, \% }\end{array}$ & $\begin{array}{c}\text { у середньому } \\
\text { на одну пару }\end{array}$ \\
\hline 5 & 6 & 30 & 92,0 & $4,6 \pm 0,22$ & $7,8 \pm 0,18$ \\
\hline 6 & 5 & 30 & 100,0 & $6,0 \pm 0,23$ & 100,0 & $6,0 \pm 0,23$ \\
\hline 7 & 4 & 28 & 81,0 & $5,7 \pm 0,34$ & 60,7 & $4,2 \pm 0,28$ \\
\hline 8 & 6 & 48 & 91,7 & $7,3 \pm 0,45$ & 91,7 & $7,3 \pm 0,45$ \\
\hline 9 & 10 & 90 & 85,6 & $7,7 \pm 0,33$ & 85,6 & $7,7 \pm 0,33$ \\
\hline 10 & 18 & 180 & 98,3 & $9,8 \pm 0,22$ & 98,3 & $9,8 \pm 0,22$ \\
\hline 11 & 7 & 77 & 78,8 & $8,7 \pm 0,36$ & 78,8 & $8,7 \pm 0,36$ \\
\hline 12 & 4 & 48 & 91,7 & $11,0 \pm 0,35$ & 72,2 & $8,7 \pm 0,18$ \\
\hline 13 & 1 & 13 & 92,3 & 12,0 & 92,3 & 12,0 \\
\hline
\end{tabular}

Загалом закритогніздні види птахів мають високу частку успішності розмноження, бо гніздо розміщене у захищеному просторі. Успішність розмноження синиць великої та блакитної, як і інших дуплогніздних птахів, гнізда яких захищені від хижаків i впливу несприятливих абіотичних факторів, стабільно висока в усіх парках міста. Безумовно, оцінюючи успішність розмноження, не можна виключати впливу антропогенного шуму (Slabbekoorn and Ripmeester, 2008), оскільки більшість підданих впливу шуму територій розташовані уздовж основних транспортних автомагістралей (Barber et al., 2009). Таким чином, стабільність структури популяцій синиць в урболандшафті забезпечується збалансованим статевим співвідношенням особин (Bekir and Tamer, 2012) 3 високими показниками продуктивності відкладання яєць та успішності розмноження.

\section{Висновки}

У парках міста повні кладки синиць великої та блакитної у середньому становлять $8,9 \pm 0,35$ та 9,5 \pm 0,33 відповідно. У синиці великої найбільшу частку складають 10- (33,5\%) та 9-яйцеві (16,7\%) кладки. У синиці блакитної переважають 10-яйцеві $(25,0 \%)$ кладки в Журавлівському гідропарку та 12-яйцеві (17,5\%) - у парку імені М. Горького. Середній показник успішності розмноження на території міста складає $85,1 \%$ у синиці великої та $84,0 \%$ у синиці блакитної. У середньому на одну пару із гнізда злітає $5,1 \pm 0,16$ у синиці великої та $8,5 \pm 0,38$ пташенят у синиці блакитної.

Протягом існування популяції синиці великої виявлене зменшення успішності розмноження: у Журавлівському гідропарку у рік розміщення штучних гніздівель із гнізд злетіло у середньому $6,7 \pm 0,12$ пташенят на одну пару, упродовж чотирьох років ця величина достовірно зменшилась майже удвічі $-3,6 \pm$ $0,15(P<0,05)$. У синиці блакитної такої залежності не виявлено. Найпродуктивнішими у синиці великої виявилися кладки третьої декади квітня - 89,7\% (8,9 \pm 0,78 пташенят на одну пару). Найуспішнішими є 10 яйцеві кладки, частка зльоту пташенят для яких становила $98,3 \%$ (9,8 $\pm 0,18$ на одну пару).

\section{Бібліографічні посилання}

Barber, J.R., Crooks, K.R., Fristrup, K.M., 2009. The costs of chronic noise exposure for terrestrial organisms. Trends Ecol. Evol. 25, 180-189.

Becker, P.H., Erdelen, M., 1982. Distridution of herring gull egg size and nest density in the mellum-colony in relation to vegetation hight. Moscow, Abst. of Symposia and Poster Presentation.

Bekir, K., Tamer, A., 2012. Offspring sex ratios and breeding success of a population of the great tit, Parus major. Zool. Middle East 57, 27-34.

Bobyliov, Y.P., Brygadyrenko, V.V., Bulakhov, V.L., Gaichenko, V.A., Gasso, V.Y., Didukh, Y.P., Ivashov, A.V., Kucheriavyi, V.P., Maliovanyi, M.S., Mytsyk, L.P., Pakhomov, O.Y., Tsaryk, I.V., Shabanov, D.A., 2014. Ecology. Folio, Kharkiv (in Ukrainian).

Broyer, J., 2009. Whibchat Saxicola rubetra reproductive success according to hay cutting schedule and meadow passerine density in alluvial and upland meadows in France. J. Nat. Conserv. 17, 160-167.

Brumm, H., Slabbekoorn, H., 2005. Acoustic communication in noise. Adv. Stud. Behav. 35, 151-209.

Bucur, V., 2006. Urban forest acoustics. Springer-Verlag, Berlin, Heidelberg.

Catchpole, C.K., Slater, P.J.B., 2008. Bird song: Biological themes and variations. Cambridge University Press, Cambridge.

Cauchard, L., Boogert, N.J., Lefebvre, L., Dubois, F., Doligez, B., 2013. Problem-solving performance is correlated with reproductive success in a wild bird population. Anim. Behav. $85,19-26$.

Dias, P.C., Blondel, J., 1996. Breeding time, food supply and fitness components of blue tits Parus caeruleus in Mediterranean habitats. Ibis 138, 644-649.

Dnondt, A., Adriaensen, F., Matthysen, E., Kempenaers, B., 1990. Nonadaptive clutch sizes in tits. Nature 348, 723-725.

Francis, C.D., Ortega, C.P., Cruz, A., 2009. Cumulative consequences of noise pollution: Noise changes avian communities and species interactions. Curr. Biol. 19, 1415-1419.

Halfwerk, W.A., Slabbekoorn, H., 2009. A behavioural mechanism explaining noise-dependent frequency use in urban birdsong. Anim. Behav. 78, 1301-1307.

Holveck, M.J., Riebel, K., 2009. Low-quality females prefer low-quality males when choosing a mate. Proc. R. Soc. (Biol.) 277, 153-160.

Howe, H.F., 1978. Initial investment, clutch size? And brood reduction in the common grackle. Ecology 59, 1109-1122. 
Koivula, K., Orell, M., Rytkönen, S., 1996. Winter survival and breeding success of dominant and subordinate willow tits Parus montanus. Ibis 138, 624-629.

Kunz, E., 2000. Genetic and environmental components of growth in nestling blue tits (Parus caeruleus). J. Evol. Biol. 13, 199-212.

Lambrechts, M.M., Aime, C., Midamegbe, A., Galan, M.J., Perret, P., Gregoire, A., Doutrelant, C., 2012. Nest size and breeding success in first and replacement clutches: An experimental study in blue tits Cyanistes caeruleus. J. Ornithol. $153,173-179$.

Leonard, M.L., Horn, A.G., 2008. Does ambient noise affect growth and begging call structure in nestling birds? Behav. Ecol. 19, 502-507.

Lloyd, C.S., 1979. Factors affecting breeding of razorbills Alca torda on Skokholm. Ibis 121, 165-176.

Makarewicz, R., Kokowski, P., 2007. Prediction of noise changes due to traffic speed control. J. Acoust. Soc. Am 122, 2074-2081.

Matveev, M.D., 1998. Ptahy rodyny synycevi (Paridae) v umovah Podillja (struktura populjacij, biologija rozmnozhennja, mizhvydovi zv'jazky) [The birds of family tits (Paridae) under conditions of Podolia (structure of populations, peculiarities of reproduction, species relations)]. Avtoreferat of dissertation for the degree of candidate of biological sciences: 03.00.08, Zoology. Kyiv (in Ukrainian).

Newell, F.L., Rodewald, A.D., 2011. Role of topography, canopy structure, and floristics in nest-site selection and nesting success of canopy songbirds. Forest Ecol. Manag. 262, $739-749$.

Orell, M., Rytkönen, S., Koivula, K., 1994. Causes of divorce in the monogamous willow tit, Parus montanus, and consequences for reproductive success. Anim. Behav. 48, $1143-1154$
Orell, M., Ojanen, M., 1983. Effect of habitat, date of laying and density on clutch size of the great tit Parus major in northern Finland. Ecography 6, 413-423.

Ouyang, J.Q., Sharp, P., Quetting, M., Hau, M., 2013. Endocrine phenotype, reproductive success and survival in the great tit, Parus major. J. Evol. Biol. 26, 1988-1998.

Padgham, M., 2004. Reverberation and frequency attenuation in forests - implications for acoustic communication in animals. J. Acoust. Soc. Am. 115, 402-410.

Paevsky, V.A., 1985. Demografija ptic [Demography of birds] Nauka, Leningrad (in Russian).

Pohl, N.U., Slabbekoorn, H., Klump, G.M., Langemann, U., 2009. Effects of signal features and environmental noise on signal detection in the great tit, Parus major. Anim. Behav. 78, 1293-1300.

Quinn, J.L., Whittingham, M.J., Butler, S.J., Cresswell, W., 2006. Noise, predation risk compensation and vigilance in the chaffinch Fringilla coelebs. J. Avian Biol. 37, 601-608.

Sanz, J.J., 2002. Climate change and breeding parameters of great and blue tits throughout the western Palaearctic. Global Change Biol. 8, 409-422.

Schaub, A., Ostwald, J., Siemers, B.M., 2008. Foraging bats avoid noise. J. Exp. Biol. 211, 3174-3180.

Slabbekoorn, H., Halfwerk, W., 2009. Behavioural ecology: Noise annoys at community level. Curr. Biol. 19, 693-695.

Slabbekoorn, H., Ripmeester, E.A.P., 2008. Birdsong and anthropogenic noise: Implications and applications for conservation. Mol. Ecol. 17, 72-83.

Tomiuk, J., Stauss, M., Segelbacher, G., Fietz, J., Kömpf, J., Bachmann, L., 2007. Female genetic heterogeneity affects the reproduction of great tits (Parus major L., 1758) in lowquality woodlands. J. Zool. Sys. Evol. Res. 45, 144-150.

Warren, P.S., Katti, M., Ermann, M., Brazel, A., 2006. Urban bioacoustics: It's not just noise. Anim. Behav. 71, 491-502.

Надійшла до редколегії 25.04.2014 